\title{
Henry van de Velde and Japanese Anonymous Design
}

At the beginning of the twentieth century, some architects abandoned the use of period styles and started designing using their own personal styles. They were subject to various influences, but one of the most important was that of Japanese art and design. Henry van de Velde was one of those artists who was strongly influenced by Japanese art and design. He was a painter for the first 10 years of his career but then changed his field to applied arts. Although masterpieces by well-known ukiyo-e painters such as Hokusai or Hiroshige were very influential for many artists, such as Vincent van Gogh, other anonymous Japanese designs seem to have been even more significant for van de Velde. The firm curve of katagami (stencil paper) is considered one of the most important sources for the restrained curve in van de Velde's Art Nouveau designs.

However, the kamon (family crest), another anonymous Japanese design, was also important to van de Velde. Various Japanese kamon were designed by unknown artisans from about the 8th century onwards. As with European coats of arms, kamon were initially held only by aristocratic families but were gradually adopted by commoners. Undoubtedly, he adapted a kamon, Tied Wild Geese, for his Tropon (1898) design, and perhaps also adapted Hawk Feathers for the cover of Also Sprach Zarathustra (1908). Monograms by van de Velde, designed for his own use and for his clients, seem to have had something to do with his interest in Japanese kamon and their usage. He emphasised the authorship of his designs by using these monograms. He was one of the most representative designers of the age of personal style. He even used monograms on an interior wall of a building he designed, as if it were one of his paintings. It is significant that van de Velde, who attached importance to authorship and emphasised his own personal style, learnt from anonymous designs such as kamon or katagami that had been designed by unknown artisans and were used by lesser-known workshops or the families of traditional Japanese society. Henry van de Velde, authorship, anonymous design, kamon (family crest), monogram

\section{Introduction}

Henry van de Velde (1863/Antwerp - 1957/Zürich) was among the first architects and designers who abandoned the use of period styles or historical revival styles and started designing using their own personal styles around the turn of the nineteenth and twentieth centuries. Progressive architects and designers such as van de Velde and Charles Rennie Mackintosh (1868-1928) became the authors of their own personal styles rather than specialists in a particular period style such as Romanesque, Gothic, Renaissance, Baroque, Rococo Revival, or Neoclassicism. From the age of Art Nouveau and Jugendstil onwards, the output of designers became known by the names of the designers rather than the period or revival styles they used for their designs. However, some of van de Velde's 
design works were based on anonymous Japanese designs. He seems to have been very much interested in the Japanese mon (crest) or kamon (family crest), which had been designed by anonymous artisans since the Nara period (c. 710-784), and katagami (stencil paper), which had been made and used by anonymous craftsmen since the Muromachi period (1336-1573).

\section{Henry van de Velde and Japanese Art and Design}

Van de Velde stopped painting around 1892 and started to produce various works of applied arts. In these works, influences from Japanese art can be pointed out. For instance, the meandering lines in Haymaker (c. 1891-1892), a sketch for tapestry in appliqué embroidery, seem to have been influenced by the suminagashi (ink marbling) technique which had been used by some ukiyo-e painters during the Edo period (1603-1867). Another ukiyo-e way of drawing meandering rivers and arrangements of standing ladies might have exerted influence on van de Velde's large appliqué embroidery Engel's Watch (1893). However, even more important to van de Velde seems to have been anonymous Japanese designs rather than famous Japanese paintings.

Researchers have found a strong relationship between the anonymous katagami and van de Velde's curved lines in some exhibition catalogues from the 1980s. Shops in Brussels started to sell imported Japanese arts and crafts in the 1880s. In van de Velde's house, Bloemenwerf, built in the Uccle (Ukkel) district of Brussels in 1895, some katagami were displayed on an interior wall. Yoko Takagi wrote that katagami's abstract curvy lines, continuous and two-dimensional, were applied to van de Velde's ornamental works, especially his two-dimensional works'. For example, van de Velde used these vigorous abstract lines on his dress designs and in his cover design for Max Elskamp's book Dominical. There is one photograph, Reception Dress (c. 1902), which shows van de Velde's wife, Maria Sèthe (1867- 1942), standing facing a wall on which two katagami are shown hanging, showing the back of the dress he designed for her. Takagi also mentioned the obvious similarities between the lines of the two katagami and the dress design. It can be said that van de Velde admitted to and expressed the katagami influence in his design.

At around the same time, van de Velde wrote about Japanese anonymous arts and crafts in L'Art Moderne, a weekly Belgian arts and literature magazine published in Brussels. He wrote that in ideal social conditions, arts and crafts are made by anonymous craftsmen as in Japan². There is another important anonymous Japanese design, kamon (family crest), which seems to have had a strong influence on van de Velde's design.

\section{Kamon (Family Crest) and Katagami (Stencil Paper)}

Although most European designers might not have known they were family crests, these crests were visually introduced into Europe in the late nineteenth century by a number of publications. Thomas Cutler called them just 'badges' in his A Grammar of Japanese Ornament and Design (London, 1880). However, a number of designers became interested in these 'badges' for their interesting form and simple beauty. For instance, an ornamental composition which applied bird design, taken from a Japanese kamon, appeared in a book Modern Ornamentation written by an English designer, Christopher

\footnotetext{
'Takagi, Y. (2012) 'Katagami and Japonisme in Belgium', Katagami Style exhibition catalogue, Nikkei Inc. , p. 283

${ }^{2}$ Van de Velde, H. (1894) 'Première prédication d'art', L'Art Moderne, 21, Janvier, pp. 4-5
} 
Dresser (1834-1904), published in 1886. Dresser, who must have had an interest in Japanese crests, used the Karigane (goose) crest to design the composition. He might have seen these crests in Cutler's book or during his visit to Japan in 1876.

Van de Velde also seems to have had a great interest in those Japanese crests. The bird-like patterns used in the Tropon advertisements were also undoubtedly taken from one of the karigane crests, Shiri-Awase Mitsumusubi Karigane (Three Tied Wild Geese) (Fig. 1). Although Maurice Rheims wrote that the only naturalistic element in van de Velde's Tropon poster is seen in the three little birds and they are strongly stylized into a triskelion in order to explain how he designed it and his taste for abstract ornament, it was a kamon made by anonymous artisans of Japan. In this case, van de Velde's discovery and application rather than his invention or design should be appreciated.
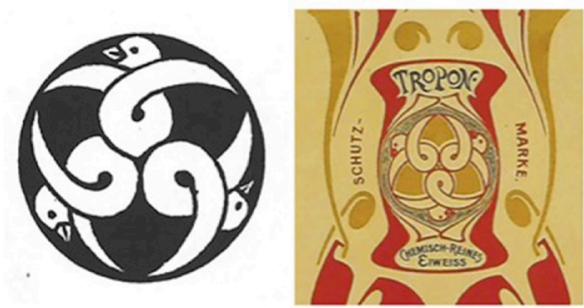

Figure 1.

Shiri-Awase Mitsumusubi Karigane (Three Tied Wild Geese) kamon (left) and the Trade Mark of 'Tropon' by Henry van de Velde (1898) (right)

Tropon was an 'Eiweiss Nahrung' produced by the Proton GmbH which had been established in Mülheim am Rhein in 1897. Because geese are thought to be an auspicious sign and seen as a symbol of power, and the flight of geese a symbol of bonding, Karigane crests were popular among samurai (military) families. Van de Velde might have not known this, although it is an appropriate information both for him and the Proton $\mathrm{GmbH}$.

The leaf-like pattern used on the cover of Also Sprach Zarathustra was perhaps taken from the Asano Takanoha (Hawk Feathers of Asano) crest, although a Celtic influence is also present. Because hawk feathers were formerly used as the feathers on an arrow, and the hawk was known as a bird which never failed to catch its prey, many military commanders preferred using Takanoha crests in the thirteenth century (Fig. 2). While the Karigane crests were mainly used by the Sanada, Inoue, and Uebayashi/Kambayashi families, the Takanoha crests were often used by the Asano, Mizutani, and Ono families
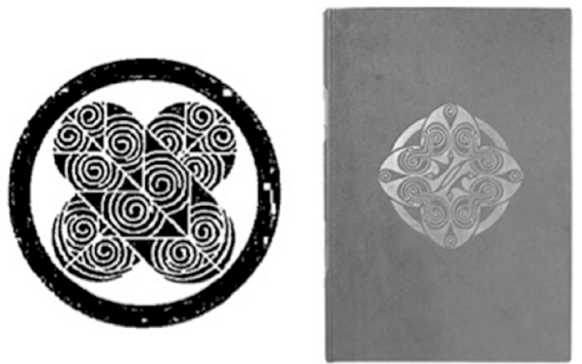

Figure 2.

Asano Takanoha (Hawk Feathers of Asano) kamon (left) and the Front Cover of Also Sprach Zarathustra by Henry van de Velde (1908) (right)

There are more than twenty thousand different kinds of family crests in Japan. Whereas Japanese family crests that were eventually refined to the neat round and square forms are almost always black and white, European coats of arms, which are usually in the shape of a shield or helmet, are drawn in combinations of scarlet, purple, black, green and some 
theme 3

identity

Figure 3.

Interior of the $\mathrm{Ha}$ vana Company Sale Room by Henry van de Velde with his monogram on its wall (1899) strand 3

authorship and anonymous design

other colours. Most of the Japanese family crests use plants or animals as their motif in a simplified form, and the majority of figures seen in kamon were developed from Japanese patterns. Kamon has been widely used in Japanese culture, for example on the kimono (Japanese traditional form of dress), lanterns, furniture, dishes, and even on gravestones. However, their origins are not precisely known. Unlike European coats of arms, which are exclusively used by royal or aristocratic families, Japanese family crests, which have been appreciated for their simple forms, are used or shared by ordinary people, although the adoption of these emblems as family crests was originally started by the elite in feudal Japan. These family crests are, in a sense, the collective form of a design idea by Japanese society.

\section{Personal Style and Anonymous Design}

Van de Velde designed and started to use his own monogram, which may have utilised the initial of his family name, ' $V$ ', around 1892. When van de Velde was a painter, he wrote his signature on his works like other painters. However, this signature was essentially limited to his early years as a painter, and by the end of the 1880s, he was using a flower-like seal instead of writing his signature on some of his works. This flower seal might have been a model of his V-like monogram, which he used on his work from at least 1892. This kind of flower seal was often used by Japanese painters. Simplification from a flower-like seal to his monogram was perhaps suggested by some characteristics of Japanese kamon. Van de Velde's preference for monograms seems to have had a connection with kamon.

Van de Velde's monogram seems to have been influenced by Japanese family crests. These family crests generally preferred curved lines to straight lines and sharp corners. Van de Velde might have simplified his flower seal design into his monogram by using some ideas of these crests. Van de Velde kept using the monogram, which is identified on the bottom right of one of his works, Haymaker, after changing his profession from painter to designer and architect. When van de Velde took charge of the interior of the Havana Company Sale Room in 1899, he placed his monogram on the interior wall of the sale room (Fig. 3).

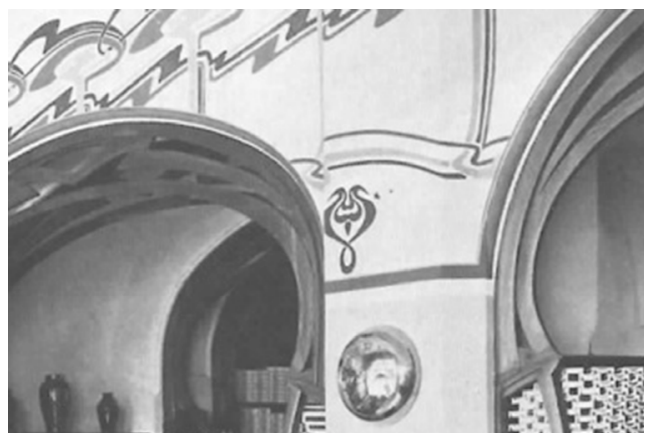

Van de Velde valued personal style very highly, while engaged in his creative work, and he is considered one of the most representative designers of early modernism. Van de Velde almost always placed monograms or signatures on his applied art works. This could be because he was a designer who began his career as a painter. For van de Velde, even architecture was a branch of the visual arts through which he could express his personal style. Hence, he placed his monograms on those works also. 


\section{Conclusion}

Van de Velde always asserted the authorship of his own design. In addition to katagami (stencil paper), which were made by anonymous artisans and used for paper stencilling in Japan, kamon (family crest) was another source of inspiration for van de Velde. It is noteworthy that Japanese anonymous designs were sources of inspiration for a designer who even put his emblem on an interior wall, just like a painter who puts a signature on a canvas. A modern architect and designer, Henry van de Velde, seems to have looked at Japanese anonymous design rather than original designs by contemporary European architects and designers. For van de Velde, the abstract shape and firm curve of kamon was not only a source of inspiration for his Art Nouveau designs but also a hint for his unique method of asserting his authorship and identity in a simple and aesthetic way.

\section{References}

Audsley, G. and Cutler, T. (1989) the Grammar of Japanese Ornament, London: Studio Editions Canning, S. (1987) Henry van de Velde (1863-1957) Paintings and Drawings, Ministry of the Flemish community

Durant, S. (1986) Ornament, A Survey of Decoration since 1830, London: John Calmann \& King, p. 184

Ito, K. (1965) Emblems of Japan, Tokyo: David Company

Mabuchi, A., Takagi, Y., Nagasaki, I. and Ikeda, Y. (2012) Katagami Style exhibition catalogue, Nikkei Inc.

Niwa, M. (1990) Japanese Traditional Patterns Volume 2, Graphic Company, pp. 121-126 Rheims, M. (1966) The Flowering of the Art Nouveau, New York: Harry N. Abrams, Inc., p. 390, p.401

Sembach, K. (1989) Henry van de Velde, New York: Rizzoli International Publications, Inc. Sembach, K. and Schulte, B. (ed.) (1993) Henry van de Velde, Een Europees Kunstenaar in Zijn tijd, Köln: Druck-\& Verlagshaus Wienand Van de Velde, H. (1962) Geschichite meines Lebens, München: R. Piper \& Co. Verlag

Figure 1. Shiri-Awase Mitsumusubi Karigane (Three Tied Wild Geese) kamon from Cutler T. (1880) A Grammar of Japanese Ornament and Design, London The Trade Mark of "Tropon" from Sembach, K. and Schulte, B. (ed.) (1993) Henry van de Velde, Een Europees Kunstenaar in Zijn tijd, Köln: Druck-\& Verlagshaus Wienand

Figure 2. Asano Takanoha (Hawk Feathers of Asano) kamon from Takasawa H. (2008) Dictionary of Family Crests, Tokyo: Tokyo-do Front Cover of Also Sprach Zarathustra (1908) from Sembach, K. and Schulte, B. (ed.) (1993) Henry van de Velde, Een Europees Kunstenaar in Zijn tijd, Köln: Druck-\& Verlagshaus Wienand

Figure 3. Interior of Havana Company Sale Room (1899) from Sembach, K. and Schulte, B. (ed.) (1993) Henry van de Velde, Een Europees Kunstenaar in Zijn tijd, Köln: Druck-\& Verlagshaus Wienand 
